\title{
Condition, Contradictions and Context of Sustainable Development Discourse in Shaping of the Built Environment
}

\author{
Dr. T. Oluseyi Odeyale, and Arc. Kayode Samuel
}

\begin{abstract}
Cities like living organisms undergo the process of birth, growth, development and death. Cities in both developing and developed world have been experiencing rapid transformation. According to Sir Winston Churchill, "we shape our buildings and afterwards our building shape us". It is important to reflect on the findings and lessons that emerge from the consideration of sustainability discourses in the transformation of the urbanity and how it has shaped the spatial complexities of the built environment. The study used a mixed methodological approach, which included participant observation and structured interviews by means of convenience and snowball sampling methods administered in the study area. Findings suggest that the traditional arrangement of these cities which is a well established one that dates back to many past generations, is increasing being changed in the face of politically motivated modernisation agenda. The challenge presented by these spatial complexities is to find the planning and design interface that will bring together the knowledge and expectations of the changing modernities as well as the embedded sociocultural practices enshrined in these traditional built environment for the benefit of the contemporary city liveability.
\end{abstract}

Keywords - City liveability, modernisation agenda, sustainability, spatial complexities, urban renewal projects.

\section{INTRODUCTION}

The transformation of the built environment and changes in urban forms has been taking place in conjunction with the increase awareness of the impact of human activities and the emergence of the concept of sustainability which is now of an international significance and concern. The concept of sustainability emerged in urban design literature in the 1970s (Arbury, 2005). The "Brundtland Report" of 1987, brought the concept of sustainability into the mainstream development discourse (WCED. 1987). Sustainability has become one of the key elements in the analysis of the growth and spatial expansion of contemporary cities; it will be of utmost importance to establish exactly what is not sustainable about the current urban environment and its attendant contradictions. This will provide an understanding of the changes to be made in the creation of a more sustainable urban future for the developing and developed countries of the world.

\subsection{Research Methodology}

The study is based on a mixed methodological approach, which included the participant observation and structured

Department of Architecture, Federal University of Technology, PMB 704 Akure, Ondo State, Nigeria. interviews by means of convenience and snowball sampling methods administration of use of exploratory questionnaires (n-410) to elicit the perceptions of urban space and its attendant transformation.

\section{THE CONTRADICTIONS AND CONCEPTS OF SUSTAINABLE DEVELOPMENT IN THE CITY}

The concepts of sustainable city exist across literature (Elkin, McLaren and Hillman, 1991; Gospodim, 2002; Gospodim, 2004; Haughton and Hunter, 1994; Sepe, 2006; Bolin, 2009). Cities like living organisms undergo the process of birth, growth, development and death. Cities in both developing and developed world have been experiencing rapid transformation which has impacted on its built environment. Cities, for centuries have been the heart, the life-blood of various civilizations, and the epicentre of economic, political and artistic activities (Spates and Macionis, 1987). This is similar to the position of Odeyale (2010), who notes that cities are usually the hub of commercial activities in the urban system. This is why Ayedun et. al (2011), describes the city as a distributional mechanism as it represents a set of human beings and their institutions interacting in a densely settled finite space, producing and distributing economic resources, service and other values. They also note that the city is a mosaic of racial, ethnic, occupational, religious and ideological groups with their differences generating interdependence and conflict.

Glaeser and Kahn (2003) believe that cities can be thought of as the absence of physical space between people and firms. They further explained that cities exist to eliminate the cost of transportation of goods, people and ideas and transportation technologies dictate urban form. Sepe (2006) argued that a city is not an artificial construct, but a set of habits, customs and lifestyles that are interrelated. These elements, according to him, should not be viewed individually as they are subsumed in the identity of the place and the identity of the city. The author went further to assert that the contemporary city is characterized by complexity, simultaneity and instability, leading to situations of transience and transformation. Bertaud (2014) describes a city as an inhabited central place different from a town or village by its size and range of activities like religious, military, political, economic, educational and culture within its boundaries that involve exercise of power over surrounding villages. This closely resembles Ebenezer Howard's approach to the city (see figure 1.) 


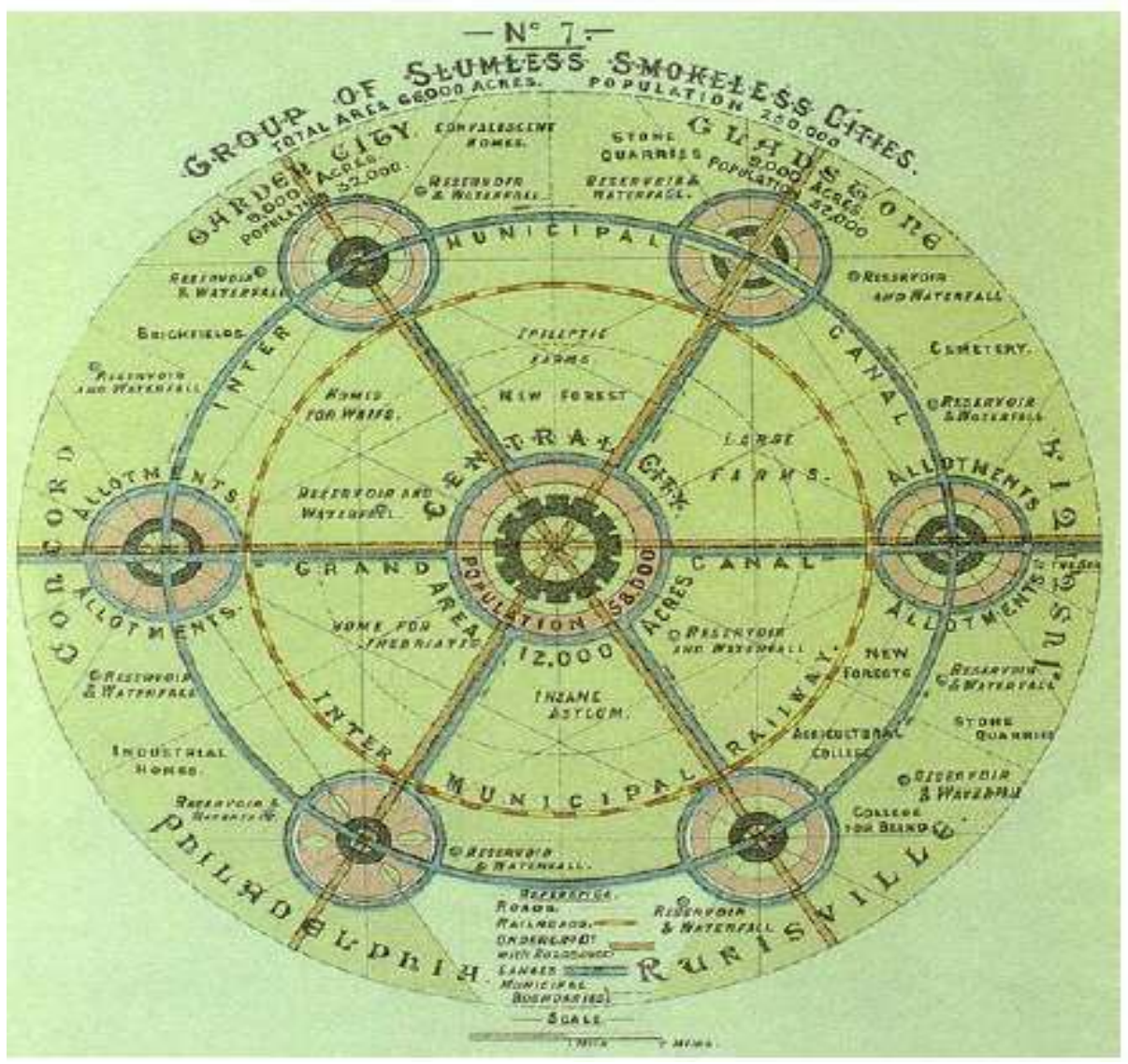

Fig. 1 Ebenezer Howard's Concept of the Garden City

Cities are seen as engines of cultural life and home to cultural heritage and events and at the same time serve as sources of cultural identity and societal transformation. This position is similar to that of Ekhaese and Adeboye (2014) acknowledging cities as major centres of economic opportunity, education and cultural life.

However, Hewitt and Hagan, (2001) suggest that sustainable development could be regarded "as a process of change in which the exploitation of resources; the direction of investments, the orientation of technological development, and institutional change are in harmony with both current and future potential to meet human needs and aspirations". Therefore in the development of the city much resources are explored and exploited in the process leading to depletion and

According to Iyengary (2015: xix) "we humans are acting as though fresh resources will be discovered to satisfy our inexhaustible need, as if there is a second Earth waiting to provide for us when we run out of supplies." It is interesting to note that history reveals multiple examples alerting us that civilizations vanish when they out-strip their resources. Now we may be approaching just such a moment on a planetary level.

\section{QUESTIONING THE ESTABLISHED APPROACH TO SUSTAINABLE DEVELOPMENT}

This paper rather questions the established approach to the study of sustainable cities and the built environment focuses on the description of physical aspects of its development. By embracing the notion of unravelling the cultural, social and anthropological meaning of planning, production, transformation and perception of space that led to societal changes within urban space usage or arrangements that is often misunderstood, ignored or altogether forgotten. It is also important to note that in order to achieve a holistic and sustainable built environment for the future of cities and urban centres (especially in the developing countries), there is the need to understand the contradictions of the background of 'soft issues' or predisposing ideas. These 'soft issues' constantly engage the notions of the production of urban and contested spaces, which can be actively seen, for example in the activities and roles of housing developing and management of urban sprawl in an emerging city or metropolis. Therefore, sustainability discourse should go beyond being a set of wishful characteristics of a future system that resolves the conflict between the various competing goals, actants, and involves simultaneously pursuits of economic prosperity, environmental quality and social and cultural equity (Hasna, 2007).

\section{FINDINGS AND DISCUSSIONS: ACCESSIBILITY AND ASSESSMENTS OF RESPONDENT'S HOME AND IMMEDIATE ENVIRONMENT}

In the study conducted for Table 1 shows the level of accessibility and Assessments of respondents' home and environment to respondents home. A critical study of the respondent's accessibility to their homes shows that one 
hundred and eighty respondents $(89.6 \%)$ can easily access their homes, while five respondents $(2.5 \%)$ have very access to their homes. Thirteen respondents $(6.5 \%)$ can access their homes with some difficulties, while three respondents $(1.5 \%)$ can hardly have access to their homes.

TABLE I ASSESSMENT OF HOME AND ITS ENVIRONMENT

\begin{tabular}{lll}
\hline Accessibility/ Assessment & Frequency & Percentage \\
\hline Inaccessible & 3 & 1.5 \\
Fairly Accessible & 13 & 6.5 \\
Accessible & 180 & 89.6 \\
Very Accessible & 5 & 2.5 \\
\hline Total & 201 & 100 \\
\hline
\end{tabular}

Source: Author's Fieldwork, 2016

Table 2 shows the level of satisfaction of respondents' living in the study area. The Table reveals that one hundred and eighty-eight respondents, representing $93.5 \%$ of the total population are not satisfied living in the area. Eight respondents, representing $4.0 \%$ of the population, are fairly satisfied with the study area, while five respondents, representing $2.5 \%$ of the population are satisfied with the area.

TABLE II RESPONDENT'S LEVEL OF SATISFACTION

\begin{tabular}{llc}
\hline Level of Satisfaction & Frequency & Percentage \\
\hline Dissatisfied & 188 & 93.5 \\
Fairly Satisfied & 8 & 4.0 \\
Satisfied & 5 & 2.5 \\
\hline Total & 201 & 100 \\
\hline
\end{tabular}

Source: Author's Fieldwork, 2016

From the two tables, looking at the study conducted to elicit the perception of urban space users, it suggests some level of contradictions. In spite of the level of infrastructures and perceived accessibility but the users are hugely unsatisfied with the quality of these urban provisions. This calls for greater need to address the relationship between people and their built environment. It also underscores the necessity to address design approaches in order to adapt, control and optimise production process of the built environment.

\section{V.CONCLUSION}

This paper has consider the concept of sustainable development and how it has trickled down to the populace It has considered various descriptions of the city that exist in the literature and how it should meet the expectations of the its inhabitants. Most of the definitions of the concept are vague as they are observed to combine the causes, characteristics of development that has consistently failed to deliver the needed dividend to the users of urban built environment. As we developed towards a sustainable built environment, it is imperative to recognize the complex nature of the society, or cities involved, as they are grounded in the cultural attributes of the local and regional identity or outlook. Hence, the sociocultural, economic and economic aspects of the studied community, or area, have to be given much greater considerations in the planning and implementation drive to achieve equitable and just society.

\section{REFERENCES}

[1] Arbury, J. (2005). From Urban Sprawl to Compact City. An analysis of urban growth management in Auckland. PhD Thesis, University of Auckland, New Zealand.

[2] Ayedun, C.;Durodola, O. and Akinjare, O. (2011). Towards Ensuring Sustainable Urban Growth and Development in Nigeria. Challenges and Strategies. Business Management Dynamics. Vol.1 No 2.

[3] Bertaud, A. (2004). "The Spatial Organization of Cities: Deliberate Outcome or Unforeseen Consequences?" Barcelona, Spain.

[4] Bolin, Rob, (2009).Sustainability of the Building Envelope. New York: Whole Building Design Group,

[5] Elkin, T.; McLaren, D. and Hillman, M. (1991). Reviving the city: towards sustainable urban development. Friends of the Earth, London.

[6] Ekhaese, E. and Adeboye, A. (2014). Go-ahead Elements of Domestic Architecture: socio-Economic and Cultural Characteristics of Residents In Benin. IMPACT: International Journal of Research in Humanities, Arts and Literature. Vol. 2, Issue 5.

[7] Glaeser, E. and Kahn, M. (2003). Sprawl and Urban Growth. National Bureau of Economic Research, Cambridge, Massachusetts. https://doi.org/10.2139/ssrn.405962

[8] Gospodim, A. (2002). "European cities and place-Identity". Discussion Paper Series, 8(2).

[9] Gospodim, A. (2004) "Urban Space Morphology and Place-Identity in European Cities; built heritage and innovative design." Journal of Urban Design, 9(2).

[10] Hasna, A.M. (2007) 'Dimensions of Sustainability'. Journal of Engineering for Sustainable Development: Energy, Environment, and Health 2 (1): 47-57.

[11] Haughton, G. and Hunter, C. (1994) Sustainable Cities. Jessica Kingsley publishers, London.

[12] Hewitt, M and Hagan, S. (ed.) (2001) City Fights - Debates on Urban Sustainability. London: James \& James (Science Publishers) Ltd.

[13] Iyengar Kuppaswamy (2015). Sustainable Architectural Design An Overview. London: Taylor \& Francis.

[14] Odeyale, T. (2010). Cultural Metamorphosis, Building Traditions and Search for Architectural Identity in Africa. In: Deependra Prashad (Ed) New Architecture and Urbanism: Development of Indian Traditions. Cambridge Publishing, Newcastle upon Tyne. Pp 54-59. https://doi.org/10.5848/CSP.1892.00007

[15] Sepe, M. (2006). "Complex Analysis for the Sustainable Planning and Construction of the Place Identify". The Sensitive Relief Method. Journal of Sustainable Development Planning. Vol 1, No.1.

[16] Spates, J. and Macionis, J. (1987). The Sociology of Cities. 2nd Edition. Wadsworth Inc.

[17] World Commission on Environment and Development. (1987) "Our Common Future". Oxford University Press, Oxford. 